\title{
Mitigation of the Global Threat of Septoria Leaf Blotch of Cereals in Algeria
}

\author{
A.Benbelkacem*, C.Djenadi**, H.Meamiche** \\ * INRA Algeria, Elkhroub field crops Exp.station, 25100. \\ ** National Agronomic Research Institute, CRP Mehdi Boualem, Baraki. Algiers. \\ benbelkacem@mail.com
}

\begin{abstract}
Septoria tritici (Mycosphaerella graminicola) and Septoria nodorum (Leptosphaeria nodorum) causal agents of Septoria leaf blotch of wheat occur throughout the major wheat growing regions in Algeria. The Septoria diseases are the source of major damage on susceptible varieties on bread and durum wheat. Surveys have been performed during the three last seasons covering most wheat growing areas of eastern (, and sub- littoral regions (Guelma, Souk Ahras, Constantine, Mila, Skikda and Bouira). The disease development was always observed except during last season where excessive drought conditions prevailed from stem elongation to boot stage of the plants. Septoria diseases were more prevalent in coastal and sub-littoral areas where risk is very high. The surveys also revealed the presence of both septoria species (M. tritici and $L$. nodorum), but septoria tritici was by far more prevalent. The National Wheat improvement Program conducted in collaboration with ICARDA conducts routine screening for resistance to septoria since the last decade; a collection of 80 durum wheat and 80 genotypes of bread wheat was tested under natural conditions at the septoria hot spot of Oued Smar (litoral center) representing high rainfall areas served as a trap nursery. Foliar diseases are normally expressed each year under these field conditions. Several wheat lines that carry resistance to Septoria leaf blotch were identified and being now used as parents to improve septoria resistance in our locally adapted varieties.
\end{abstract}

Keywords: septoria leaf blotch, wheat, surveys, resistance, Eastern Alger

\section{INTRODUCTION}

Wheat is one of the major crops that are central to achieving development in agriculture and the most important cereal crop in area coverage and production in Algeria. On average, from 2004-2013, wheat production covered 2.2 million hectares of land, and yielded on average 4.1 million metric tons of wheat per year. In northern growing region, wheat is a major cereal crop for securing food security (Benbelkacem 1991).

Despite the availability of wheat varieties with a yield potential of 4 to $5 t /$ ha under dryland systems, the actual national average yield is not more than $2 \mathrm{t} / \mathrm{ha}$ (Benbelkacem 1991). The low production and productivity of the crop is attributed to diverse and enigmatic constraints: abiotic, biotic, socio-economic and those related to crop management.

The world's wheat supplies have been threatened by diseases for centuries. Wheat occupies 2.2 Million hectares in Algeria; total wheat production is 3.2MMT. In order to compensate for low production, 50 MMT are imported annually. Septoria leaf blotch, caused by Septoria tritici is one of the most damaging diseases of wheat in cereal regions of Algeria, causing significant losses to yield and quality in years with apropriate conditions. It is one of the most aggressive diseases on common wheat (Triticum aestivum L.) and durum wheat (T. turgidum L. var. durum) worldwide (Zillinsky. 1983, Kema et al,.1996). This disease is by far the most important disease in Northern and Eastern Africa and the Middle East. The disease prevalence changes from year to year and from region to region, depending on climatic conditions and variety grown. The combination of mild winter temperatures with high humidity in areas where susceptible wheat varieties are grown on large scale, creates the perfect conditions for the leaf blotch pycnidiospores to spread rapidly.

Septoria epidemics have destroyed, in the past, many well established wheat varieties in Algeria in the 1990s and 2000s mainly in the areas receiving 350mm and more (figure.1). In 2004, the production loss by Hidhab bread wheat cultivar in Algeria was estimated at 100000 tons, i.e. 50 million US $\$$ in a single year. In North Africa (Morocco, Algeria, Tunisia), epidemics occurred in 1977, 2004, and 
2009. Emerging races are showing adaptation to extreme temperatures an adaptation which were never seen before. In 2011, septoria epidemics in North Africa (Algeria, Morocco and Tunisia) was caused by a virulent race called "warrior" against which the most widely used resistance gene Yr27 has become ineffective.

The transboundary nature of septoria pathogen coupled with the ability for mutation and recombination of virulence in pathogen population which is now proven and found in Algeria, along with the large effect of environmental conditions are some of the major driving forces in septoria outbreak.

In Algeria, genetic uniformity caused by mega-varieties, and overlapping and/or continued cultivation of susceptible varieties constitutes a real weakness.

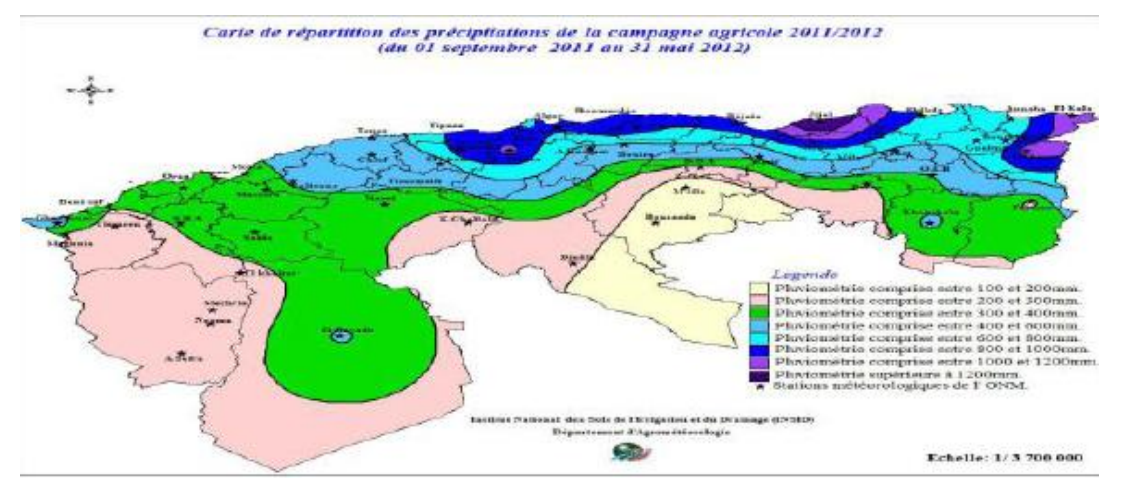

Figure1. Rainfall distribution in northern Algeria

To address this issue Algeria used strategies for immediate action, medium term protection and longterm research efforts to develop new resistant wheat varieties. Ongoing yearly surveillance in all wheat area, awareness, and early warning systems to farmers; and breeding and developing new varieties with high yield potential and durable resistance are the adopted strategies to reduce the risk of septoria. Several highly resistant varieties (Tiddis, Boumerzoug, Massine, Akhamokh and Yacine) were selected and promoted following seed multiplication and commercial release. They are free of septoria and yellow rust and widely used in crosses to improve resistance of the local varieties. The newly released varieties are being distributed to farmers to replace their susceptible varieties. All old and susceptible varieties are withdrawn gradually by the seed companies. These new released resistant varieties are deployed in different cereal growing areas providing a natural barrier between eastern to western Algeria to intercept the major direction of air flow. Fungicide control is now routinely applied soon after diseases detection or even preventively. The level of awareness for septoria leaf blotch across Algeria is now very high. Training among farmers for visual detection is widely promoted by plant protection and extension services. These strategies have been very effective in mitigating the threat of wheat stripe rust such that losses have not exceeded $10 \%$ over the last five years. The occurrence and the variability of septoria in most wheat genotypes (esp. bread) is of concern, as it is expected to have a major economic significance in the high plateau areas of Algeria, especially with climate changes.

For this reason, the assessment of disease is the basis of epidemiology, which is the study of disease at the level of populations of pathogens and hosts. It is also the basis of the study of the effects of disease on crop yield and of disease forecasting, which involves the prediction of the amount of disease that is likely to occur at some time and spatial in the future. Thus, surveys were carried out aiming at monitoring the disease status and relative economic influences over season and variation with climate change; trapping of $S$. tritici through establishing "Trap Nurseries" at hot spots of the study area to determine pathogen pressure and reaction of wheat genotypes under field condition.

Tackling Septoria leaf blotch will have positive impact on the global food security: work on Septoria in Algeria is being an integral component of the Food security concern; thus creating and disseminating cultivars with continually improved resistance was one of our main goals. Mitigating septoria leaf blotch was done trough launching and operating a national network of NARS, technical and national plant protection institutes. Major outputs are sought for this netwrok: 1) Tracking and monotoring the global yellow rust populations, 2) breeding durably resistant and high yielding wheat varieties to yellow rust, 3 ) accelerated seed delivery system to combat threat of rusts, 4) capacity development for individuals, institutions and networks for a sustainable impact. 


\section{MATERIAL AND MeTHODS}

Tracking and monotoring global septoria populations in wheat growing areas (Northern algeria)Survey of septoria leaf blotch of wheat is carried out in northern zones of Algeria for three consecutive cropping seasons (2011-2014) to monitor the disease statues. The disease survey was concentrated in the main different major wheat grown governorates (Guelma, Souk Ahras, Skikda, Constantine, Mila and Bouira). Roadside wheat fields were visited and data were collected from each $10-15 \mathrm{~km}$ stops as per wheat fields available. The incidence of the disease was calculated using the number of infected plants expressed as a percentage of the total number of plants assessed. Similarly, the severity of the disease was examined visually on the whole plants within the quadrants and recorded as the percentage of plant part (tissue) affected (percentage of septoria infection of the plant), and plant response (type of infection) using Saari \& Prescott scale, 1975 and and Eyal scale for pycnidial coverage of the leaf (Eyal \& Brown, 1976; Jlibene et al., 1982 ; Eyal et al. 1987). The prevalence of the disease was computed using the number of fields affected divided by total number of fields assessed expressed in percentage.

\subsection{Breeding Durably Resistant and High Yielding Wheat Varieties to Septoria Leaf Blotch}

The whole wheat collection of the national wheat breeding program comprising 80 entries of durum wheat and 80 of bread wheat served as trap nursery experiment conducted in Oued Smar district of Algiers (hot spot for diseases) during three seasons (2011 to2014). Each entry was planted in a nonreplicated augmented design with four rows of $1 \mathrm{~m}$ spaced at $20 \mathrm{~cm}$. Plot length was $100 \mathrm{~cm}$. Susceptible checks, Hidhab, Morocco, Cirta and waha were included in every 10 entries in the blocs. Per cent severity (pycnidial coverage) was recorded three times, starting when Hidhab reached the scale of 2 according to the Saari \& Prescott scale [9] and 20\% pycnidial leaf coverage (Eyal \& Brown, 1976).

\section{RESULTS AND DISCUSSION}

\subsection{Survey of Septoria Leaf Blotch in Wheat Growing Areas of Eastern Algeria}

Table1. Septoria wheat disease status in Eastern Algeria (2011-2014)

\begin{tabular}{|c|c|c|c|c|c|c|}
\hline \multirow[t]{2}{*}{ Area } & \multirow[t]{2}{*}{ data } & & & Season & & District \\
\hline & & & $2011 / 12$ & $2012 / 13$ & $2013 / 14$ & mean \\
\hline \multirow[t]{4}{*}{ Mila } & \multicolumn{2}{|l|}{ Surveyed fields } & 21 & 25 & 20 & \\
\hline & \multicolumn{2}{|l|}{ Prevalence $(\%)$} & 90 & 88 & 47 & 75 \\
\hline & \multirow{2}{*}{ Incidence (1-9) } & Range & $3-6$ & $2-7$ & $1-3$ & \\
\hline & & Mean & 2.2 & 3.4 & 1.7 & \\
\hline \multirow[t]{4}{*}{ Constantine } & \multicolumn{2}{|l|}{ Surveyed fields } & 28 & 21 & 23 & \\
\hline & \multicolumn{2}{|l|}{ Prevalence $(\%)$} & 91 & 84.2 & 40 & 71.7 \\
\hline & \multirow[t]{2}{*}{ Incidence (1-9) } & Range & $2-5$ & $2-6$ & $1-3$ & \\
\hline & & Mean & 1.8 & 2.7 & 1.8 & \\
\hline Guelma/ & \multicolumn{2}{|l|}{ Surveyed fields } & 25 & 18 & 20 & \\
\hline Souk Ahras & \multicolumn{2}{|l|}{ Prevalence $(\%)$} & 74.3 & 82.3 & 55.6 & 70.7 \\
\hline & \multirow[t]{2}{*}{ Incidence (1-9) } & Range & $2-7$ & $2-6$ & $1-4$ & \\
\hline & & Mean & 3.1 & 2.5 & 1.4 & \\
\hline \multirow[t]{4}{*}{ Skikda } & \multicolumn{2}{|l|}{ Surveyed fields } & 14 & 10 & 15 & \\
\hline & \multicolumn{2}{|l|}{ Prevalence $(\%)$} & 90 & 91 & 60 & 80.3 \\
\hline & \multirow[t]{2}{*}{ Incidence (1-9) } & Range & $2-8$ & $2-7$ & $2-4$ & \\
\hline & & Mean & 1.9 & 2.6 & 2.4 & \\
\hline \multirow[t]{4}{*}{ Grand total } & Surveyed fields & & 96 & 84 & 87 & \\
\hline & Prevalence $(\%)$ & & 84.7 & 85.7 & 45.5 & 71.9 \\
\hline & \multirow[t]{2}{*}{ Incidence (1-9) } & Range & $1-8$ & $2-7$ & $1-4$ & \\
\hline & & Mean & 2.3 & 2.7 & 1.8 & \\
\hline
\end{tabular}

Septoria surveys conducted for three consecutive seasons (2012-2014) in 96, 84 and 87 wheat fields respectively around five districts of central and eastern regions of Algeria revealed that disease incidence vary from low to high infection of wheat fields depending on the crop species (durum or bread), variety and climatic conditions. The disease was observed in almost all surveyed areas at variable levels. Average disease prevalence reached $71.9 \%$ of inspected fields with a range of $65.3 \%$ to $80.3 \%$ at Bouira and Skikda districts respectively (Table 1). Of 96 wheat fields inspected in 
2011/2012, 84.7\% were infected with septoria leaf blotch with an incidence varying from 1 in some fields of Bouira district up to 8 in some fields of Skikda (1-9 scale).

During 2012/2013 season, the same trend was observed on average for disease prevalence $(84.7 \%$ vs 85.7\%) and incidence in inspected fields; but in 2013/2014, we observed lower diseases occurrence and distribution in all surveyed districts.

Prevalence of septoria was as low as $35 \%$ at Bouira to $60 \%$ at Skikda with an overall average of $45.5 \%$. The incidence of the disease ranged from 1 to 3 in the 1 to 9 scale.

Result of the third (2013/14) year of survey indicated that prevalence and incidence were much lower mainly because of the drought stress that affected the plants during stem elongation and anthesis stage

Table2. Rainfall mean oversites during the years of surveys in Eastern Algeria.

\begin{tabular}{|l|c|c|c|c|c|c|c|c|c|c|}
\hline \multicolumn{1}{|c|}{ Months } & Oct & Nov & Dec & Jan & Feb & Mar & Apr & May & Jun & Total mm \\
\hline $2011-12$ & 28,5 & 54,2 & 48,2 & 94,7 & 45,8 & 44,1 & 68,5 & 60,2 & 28,6 & $\mathbf{4 7 2 , 8}$ \\
\hline $2012-13$ & 27,9 & 49,8 & 60,3 & 58,3 & 59,2 & 49,7 & 73,5 & 48,6 & 14,9 & $\mathbf{4 4 2 , 3}$ \\
\hline $2013-14$ & 23,6 & 98,1 & 42,2 & 57,7 & 53,2 & 97,4 & 6,4 & 20,9 & 28,9 & $\mathbf{4 2 8 , 4}$ \\
\hline 25years average & 38,6 & 44,6 & 73,2 & 62,8 & 53,8 & 56,2 & 59 & 52,3 & 19,3 & $\mathbf{4 5 9 . 8}$ \\
\hline
\end{tabular}

From table 2, we can then see that rainfall was low during the months of april and may of 2014 and total rainfall in 2013/2014 season was lowest than the other seasons or the 25 years average and thus pathogens could not develop much.

\subsection{Response of Commercial Varieties to Septoria on Farmers Field}

To assess the real level of wheat infection, we had to follow and study the reaction of the different old and new commercial varieties on a sample of farmer fields. This was only done in 2012/2013cropping season

Table3.Reaction of wheat varieties to septoria leaf blotch in Algeria in 2012/2013

\begin{tabular}{|c|c|c|c|c|c|c|}
\hline \multirow{2}{*}{ Variety } & \multirow{2}{*}{$\begin{array}{c}\text { No of } \\
\text { fields } \\
\text { inspected }\end{array}$} & Prevalence & \multicolumn{2}{|c|}{ Incidence $(\%)$} & \multicolumn{2}{|c|}{$\begin{array}{l}\text { Pycnidial coverage } \\
\text { (Severity) }(\%)\end{array}$} \\
\hline & & (o/) & Range & Mean & Range & Mean \\
\hline Hidhab (BW) & 15 & 93 & $3-8$ & 5.2 & $35-75$ & 45 \\
\hline Arz (BW) & 12 & 66 & $1-4$ & 1.7 & $10-25$ & 18 \\
\hline Aïn Abid (BW) & 10 & 35 & $1-3$ & 1.2 & $10-15$ & 12 \\
\hline Akhamokh(BW) & 06 & 10 & $1-2$ & 1.3 & $\operatorname{Tr}-10$ & 05 \\
\hline Cirta (DW) & 08 & 78 & $4-7$ & 5.1 & $30-60$ & 40 \\
\hline Waha (DW) & 18 & 56 & $3-6$ & 4.2 & $30-45$ & 35 \\
\hline Wahbi (DW) & 07 & 55 & $3-6$ & 3.9 & $20-40$ & 30 \\
\hline Beni Mestina (DW) & 05 & 10 & $1-3$ & 1.6 & $10-15$ & 12 \\
\hline
\end{tabular}

\section{BW: Bread wheat. DW: Durum wheat.}

In bread wheat fields, varieties Hidhab and Arz had a disease prevalence of $93 \%$ and $66 \%$ respectively; fields of Ain Abid a cultivar selected later showed a prevalence of $35 \%$ and the newest cultivar Akhamokh showed a 10\% field infection by septoria leaf blotch which is the smallest reaction (Table 3). We can see the same reaction with durum wheat fields where the oldest varieties Cirta, Waha and Wahbi showed a larger disease prevalence than the newly selected cultivar Beni Mestina with $78 \%, 56 \%$ and $55 \%$ respectively.

Disease incidence was high in the bread wheat Hidhab (5.2 in the 1 to 9 scale); the other bread wheats had a much lower disease incidence (1.2 to 1.7). In the durum wheat, Cirta, Waha and Wahbi had an incidence ranging from 3.9 to 5.1; Beni Mestina was at 1.6 incidence only.

If Hidhab, cirta, waha and wahbi had a pycnidial coverage of the leaves ranging from 30 to $45 \%$ on average, the other varieties of bread or durum wheat had a leaf pycnidial coverage of $5 \%$ to $18 \%$ (Figure 2). 


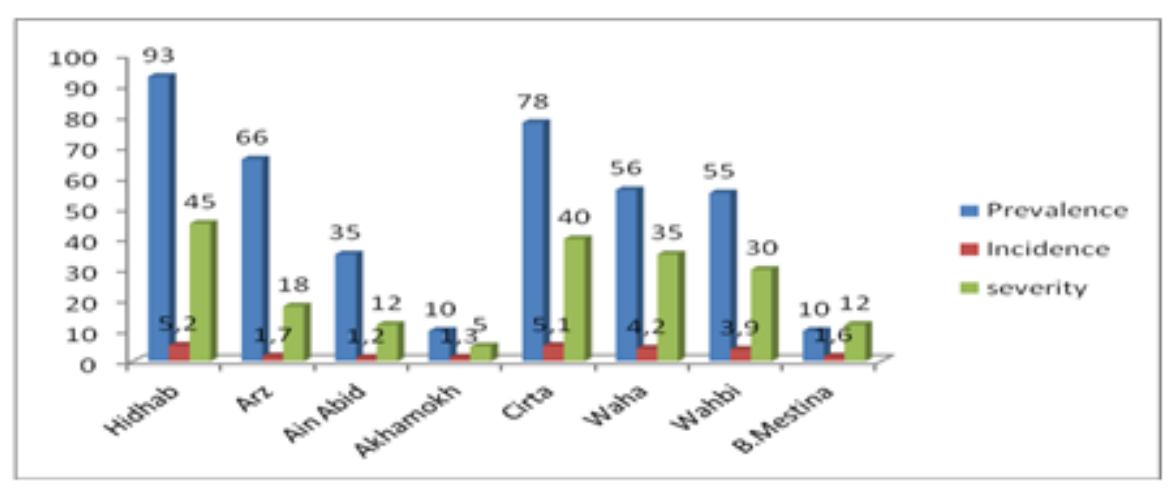

Figure 2. Prevalence, disease incidence and severity of septoria on commercial farmer wheat fields in $2012 / 2013$.

\subsection{Reactions of commercial and new varieties of bread and durum wheat to septoria tritici (Wheat diseases trap nursery)}

Of 160 wheat genotypes evaluated, 55.6\% were infected with an incidence of septoria leaf blotch above 3 in the 1 to 9 scale (Saari \& Prescott, 1975).

The highest incidence reached the level of 5 in durum wheat (Hedba3, Senator capelli and Kronos) and 5 to 6 in bread wheat (Hidhab, Morocco, Benmabrouk, Mahon Demias and Mexipak). Durum wheat cultivars were in general less affected than bread wheats with $20.6 \%$ versus $35 \%$ respectively but this level is already a threat (tables 4 and 5).

Table 4. Septoria trap nursery of commercial and candidate varieties to septoria (1-9scale).

\begin{tabular}{|c|c|c|c|c|c|}
\hline$\underline{\mathbf{N}^{\circ}}$ & Variety & Incidence & $\underline{\mathbf{N}^{\circ}}$ & Variety & Incidence \\
\hline$\overline{1}$ & HEIDER & 3 & $\overline{41}$ & $\overline{\mathrm{ZB} / \mathrm{FG}}$ & 2 \\
\hline 2 & MEXICALI (ACSAD 65) & 2 & 42 & KEBIR & 2 \\
\hline 3 & Aghrass-1/Bezaiz98-1=ICAMOR-TA04-5 & 2 & 43 & SENATORE-CAPELLI & 5 \\
\hline 4 & WOLLAROI & 2 & 44 & T.POLONICUMxZB & 4 \\
\hline 5 & TITAN & 2 & 45 & CLAIRDOC & 2 \\
\hline 6 & KRONOS & 5 & 46 & AGATHE & 2 \\
\hline 7 & CHACAN & 3 & 47 & MOHAMED BEN BACHIR & 2 \\
\hline 8 & CAPEITI 8 & 1 & 48 & MONT PELLIER & 3 \\
\hline 9 & WAHA & 4 & 49 & HEDBA-03 & 5 \\
\hline 10 & ENTE MARIO / CANDO & 2 & 50 & BIDI 17 & 4 \\
\hline 11 & FG/Palest,20C/606//Mexi/3/Rabi & 2 & 51 & OUED ZENATI368 & 4 \\
\hline 12 & SABIL - 1 & 2 & 52 & USDA 7317 & 3 \\
\hline 13 & MRB 5 & 2 & 53 & DJENNAH-KHETIFA & 4 \\
\hline 14 & SABIL -1 & 2 & 54 & GUEMGOUM RKHEM & 2 \\
\hline 15 & REZZAK & 2 & 55 & GLOIRE DE MONT GOLFIER & 2 \\
\hline 16 & MRB 17 & 2 & 56 & BELIOUNI & 2 \\
\hline 17 & TELSET & 2 & 57 & GTA/DUR... & 3 \\
\hline 18 & 920777 & 1 & 58 & SIMETO & 3 \\
\hline 19 & SILLIANA & 2 & 59 & KUCUK & 2 \\
\hline 20 & TEZ / FRI //WULP & 2 & 60 & DUKEM-12/2*RASCON-21 & 2 \\
\hline 21 & CANNIZZARA & 2 & 61 & PLATA-1/SNM//PLATA-9 & 2 \\
\hline 22 & KAMILLAROI & 3 & 62 & GIDARA-2 & 2 \\
\hline 23 & CHEN 'S' & 2 & 63 & SOOTY-9/RASCON-37 & 2 \\
\hline 24 & AWL $2 /$ BIT & 2 & 64 & YAVAROS-79 & 3 \\
\hline 25 & T,POLONICUM ZB // GDO VZ... & 4 & 65 & AJAIA-12/F3LOC(sel.eth.135) & 2 \\
\hline 26 & OMSNINA-1 & 2 & 66 & Barba de Lobo & 2 \\
\hline 27 & CAMADI ABOU $73 \mathrm{~N}^{\circ} 7510$ & 2 & 67 & Karasu & 2 \\
\hline 28 & JORDAN COLLECT SEN N ${ }^{\circ} 53$ & 3 & 68 & Jordan Collect.86 & 4 \\
\hline 29 & JORI C69 & 2 & 69 & Néodur & 2 \\
\hline 30 & SEBOU & 2 & 70 & Orjaune & 2 \\
\hline 31 & GUEROU -1 & 2 & 71 & Om Rabi 6 & 2 \\
\hline 32 & OM RUFF 2 & 2 & 72 & Boussellem & 3 \\
\hline 33 & HOGGAR (VITRON) & 3 & 73 & Ahlal & 2 \\
\hline
\end{tabular}




\begin{tabular}{|c|c|c|c|c|c|}
\hline 34 & KORIFLA = SHAM -3 & 2 & 74 & Carnavaca Colorado & 2 \\
\hline 35 & GRANIZO & 2 & 75 & D 94-567 & 2 \\
\hline 36 & CHEN 'S' /ALTAR 84 & 2 & 76 & 904"S"/Logh"S" & 3 \\
\hline 37 & CHEN 'S' /AUK & 2 & 77 & Poggio & 2 \\
\hline 38 & TELL 76 & 2 & 78 & Arment//SRN 3/Nigris4/3/Canelo & 2 \\
\hline 39 & TASSILI (RABI/FG) & 2 & 79 & Somat 4/Inter 8 & 2 \\
\hline 40 & INRAT 69 & 4 & 80 & Ofonto & 2 \\
\hline
\end{tabular}

Table 5. Septoria Bread wheat trap nursery incidence (1-9scale)

\begin{tabular}{|c|c|c|c|c|c|}
\hline 1 & HIDHAB(HD1220.....) & 6 & 41 & ATTILA $* 2$ // CHIL /BUC & 2 \\
\hline 2 & MAHON DEMIAS & 5 & 42 & PBW65 / 2*PASTOR & 3 \\
\hline 3 & ANZA & 3 & 43 & GEN*2//BUC/FLK/3/2*PASTOR & 2 \\
\hline 4 & ARZ & 2 & 44 & WEAVER / PRINIA & 3 \\
\hline 5 & AIN ABID(AS81189A) & 1 & 45 & BOW / PRL // BUC /3/ WH576 & 3 \\
\hline 6 & ZIAD & 3 & 46 & PRL/SARA//TSI/VEE\#5/3/DUCULA & 2 \\
\hline 7 & FLORENCE AURORE & 3 & 47 & CHOIX/STAR/3/HE1/3*CNO79//2*SERI & 2 \\
\hline 8 & SAHL & 2 & 48 & KAUZ / PASTOR & 2 \\
\hline 9 & GIZA163 & 2 & 49 & Weaver/4/Nac/Th.AcC//3*Pvn/3/Mirlo/Buc & 3 \\
\hline 10 & GIZA164 & 2 & $\mathbf{5 0}$ & Chen/Aeg Sqar(taus)//Bcn/3/2*Kauz & 2 \\
\hline 11 & WH542 & 3 & 51 & BOW/URES//2*WEAVER/3/BOW/PRL//BUC & 3 \\
\hline 12 & INQILAB91 & 2 & 52 & FALK*2/BISU/3/CHEN/... & 2 \\
\hline 13 & SAKHA & 4 & 53 & BENMABROUK & 5 \\
\hline 14 & TUI & 3 & 54 & HPO/TAN//VEE/3/2*PGO/4/MILAN/5/SERI1 & 2 \\
\hline 15 & SAGITARIO & 3 & 55 & Milan/S87230//Huites & 3 \\
\hline 16 & SUPER SERI \# 2 & 2 & 56 & Kauz//Altar 84/AOS/3/Milan/Kauz/4/Huites & 2 \\
\hline 17 & SUPER SERI \# 1 & 2 & 57 & Reh/Hare//2*Bcn/3/Croc-1/Ae.Squar... & 2 \\
\hline 18 & JAGGER & 2 & 58 & ATTILA/3*BCN//BAV92/3/TILHI & 2 \\
\hline 19 & BAVIACORA-M92 & 3 & 59 & Milan/otus//Attila/3*Bcn & 3 \\
\hline 20 & PUNJAB.96 & 3 & 60 & OASIS/SKAUZ//4*BCN*2/3/PASTOR & 1 \\
\hline 21 & SULTAN.95 & 2 & 61 & Nac/Th.Ac//3*Pvn/3/Mirlo/Buc/4/2*Pastor & 2 \\
\hline 22 & CHAM-6 & 3 & 62 & WBLL1/KAMB1//PASTOR & 2 \\
\hline 23 & SUPER SERI \# 3 & 2 & 63 & KAMB $1 * 2 /$ KUKUN & 3 \\
\hline 24 & MEXIPAK & 5 & 64 & WBLL1*2/TUKURU & 3 \\
\hline 25 & CHAM-4 & 2 & 65 & T,Monococcum Deriv. & 1 \\
\hline 26 & NESSER TALL & 2 & 66 & Barleta Benvuto & 2 \\
\hline 27 & SONALIKA & 2 & 67 & WBLL1*2/TUKURU & 2 \\
\hline 28 & CHIL / PRL & 2 & 68 & Buck Buck & 3 \\
\hline 29 & NESSER DWARF & 2 & 69 & Compair & 2 \\
\hline 30 & PASTOR & 1 & 70 & Thatcher & 2 \\
\hline 31 & HXL $7579 / * 2 B A U$ & 2 & 71 & TC*6x/Exchange (RL6004) & 2 \\
\hline 32 & PBW343 & 4 & 72 & Gatcher (w3201) & 2 \\
\hline 33 & DHARWAR DRY/NESSER & 1 & 73 & WL711 & 3 \\
\hline 34 & PASTOR //SITE /MO/3/ / . . & 1 & 74 & Yr6/6* Avocet S & 1 \\
\hline 35 & CHEN/Ae Squa(taus)//BCN/3/... & 2 & 75 & Yr8/6* Avocet S & 1 \\
\hline 36 & PASTOR/BAV92 & 2 & 76 & Ghurab2 & 2 \\
\hline 37 & IRENA / BABAX // PASTOR & 2 & 77 & Bohouth 6 & 2 \\
\hline 38 & CROC-1/AE.Sq//OPATA/3/.. & 2 & 78 & Memof 22 & 3 \\
\hline 39 & Gen*2//Buc/Flk/3/2*Pastor & 2 & 79 & Seri 82 & 2 \\
\hline 40 & VEE/MJI/2*TUI/3/2*PASTOR & 2 & 80 & Morocco & 5 \\
\hline
\end{tabular}

\section{DISCUSSION}

Septoria occurrence is known to expand quickly after its declaration, mainly when conditions of dissemination are present (cool temperatures, rainfall). In this study, the wide distribution across seasons 2011/2012 and 2012/2013 could be due to the favorable climatic conditions and mainly rain occurence. For instance, the disease was less important in the third cropping season. The variation over season and location could probably depend on the type of wheat cultivars grown Singh, RP. 1991. , and on the predominant environmental conditions, especially temperature (Roelfs et al., 1992). Moreover, most probably the frequency of favorable environments such as long duration of rainy and cloudy sky could raise the humidity that is suited for the formation of free moisture on plant surface. 
Moreover, the high level of septoria incidence recorded during the study period in the wheat growing areas of Skikda and Mila for exemple might be the result of cultivation of susceptible wheat cultivars such as Hidhab in bread wheat and Cirta in durum wheat.

According to this study, these susceptible cultivars accounted for more than 70 per cent of the wheat. Experience with wheat production in the last two decades showed that new septoria races continually appear and become real threats to the breakdown of many high yielding commercial wheat cultivars (Ayele et al, 2008). This field assessment also showed the susceptibility of commercial bread wheat varieties to septoria leaf blotch when they were compared to durum wheat varieties. The high level of septoria severity (pycnidial cover) was recorded in Hidhab or Morocco cultivars.

The use of resistant variety is the best control strategy of wheat diseases (Arraiano L.S. \& Brown J.K.M., 2006) for resource poor farmers in developing countries and the most environmentally friendly and profitable strategy for commercial farmers (Singh et al., 2006). A variation in resistance spectrum was observed between durum and bread wheat cultivars in the trap nursery installed at a hot spot. More than $55.6 \%$ of the cultivars were susceptible to the race populations of the pathogen.

\section{CONCLUSION}

Biotic stresses are important in different wheat growing areas of Algeria; they are surely having a serious impact on wheat production. Climatic changes will enlarge this effect in most growing areas of Algeria. Mitigating of the global threat of wheat septoria in Algeria is though very important. Actions should be continuously taken to face all these biotic stresses and avoid pathogen dissemination. Gene deployment is one of the key issues to accelerate seed delivery of resistant varieties.

\section{REFERENCES}

Arraiano L.S. \& Brown J.K.M., 2006. Identification of isolate-specific and partial resistance to septoria tritici blotch in 238 European wheat cultivars and breeding lines. Plant pathology, $55: 726-738$.

Ayele, B., Eshetu, B., Betelehem, B., Bekele, H., Melaku, D., Asnakech, T., Melkamu, A., Amare, A., Kiros, M., and Fekede, A. 2008. Review of two decades of research on diseases of small cereal crops. In: Abrham Tadesse (eds.) Increasing crop production through improved plant protection Vol I. Proceedings of $14^{\text {th }}$ annual conference of plant protection society of Ethiopia 19-22 Dec. 2006 Addis Ababa., Ethiopia pp 375-416.

Benbelkacem. A. (1991). Les céréales d'hiver. In Céréaliculture 25. ITGC.

Eyal Z., \& Brown M.B., 1976. A quantitative method for estimating density of septoria tritici pycnidia on wheat leaves. Phytopathology, $66: 11-14$.

Eyal. Z, Scharen. A. L, Prescott. J. M et Van Ginkel. M. (1987). The Septoria diseases of wheat: concepts and methods of disease management. CIMMYT, Mexico. pp 45.

Jlibene M., Gustafson J.P. \& Rajaram S., 1982. A field disease evaluation method for selecting wheats resistant to Mycosphaerella graminicola. Plant Breeding, 108 : 26-32.

Kema G.H.J., Yu D.Z., Rijkenberg F.H.J., Shah M.W \& Baayen R.P., 1996. Histology of the pathogenesis of Mycosphaerella graminicola in wheat. Phytopathology, 86 : 777-786.

Roelfs, AP, Singh, RP, and Saari, EE. 1992. Rust Diseases of Wheat: Concept and Methods of Disease Management. Mexico, D.F: CIMMYT. pp 81.

Saari, E.E \& J.M.Prescott, 1975. A scale for appraising the foliar intensity of wheat diseases. Plant Disease report. 59: 377-380.

Singh, RP. 1991. Pathogenecity variation of $P$. recondita f. sp. tritici and $P$. graminis f. sp. tritici in wheat growing areas of Mexico during 1988-1989. Plant Disease 75: 790-794.

Singh, RP, Hodson, DP, Jin, Y, Huerta-Espino, J, Kinyua, MG, Wanyera, R, Njau, P, and Ward, RW. 2006. Current status, likely migration and strategies to mitigate the threat to wheat production from race Ug99 (TTKS) of stem rust pathogen. Perspectives in Agriculture, Veterinary Science, Nutrition and Natural Resources 1: 1-13.

Zillinsky F.J. (1983). Maladies commune des céréales à paille: Guide d'identification. CIMMYT, Mexico. 141p. 


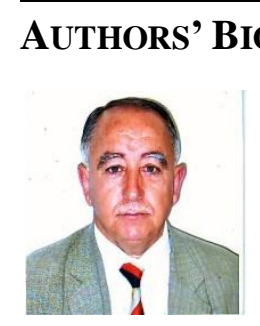

BENBELKACEM Abdelkader, PhD. Director of the Research on Biotechnology and plant breeding Division. National coordinator of the wheat improvement program of Algeria. Associate professor at the University of Constantine.

FIELDS OF INTEREST: Plant breeding, plant pathology.

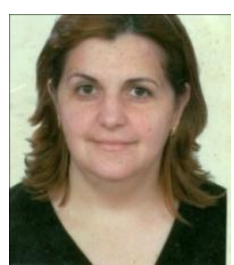

Mrs DJENADI CHAFIKA, Researcher (Wheat Breeding), Biotechnology and Plant Breeding Division. National Agronomic Research Institute of Algeria (INRAA). CRP Mehdi Boualem. ALGIERS. PhD graduate.

FIELDS OF INTEREST Use of conventional and biotechnology tools for wheat disease breeding

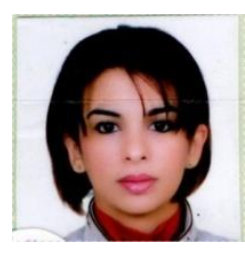

MEAMICHE NEDDAF Hayet, Plant pathologist on wheat diseases. PhD student and researcher at the National Institute of Agricultural Research of Algeria (INRAA). Main research interest: studying plant/pathogen interactions, resistance of wheat against major fungal diseases present in Algeria and integrated pest management. FIELDS OF INTEREST Use of conventional and biotechnology tools for wheat disease breeding. 